\title{
PENANGANAN AWAL KEJADIAN PREEKLAMSIA BERAT DAN EKLAMPSIA SALAH SATU RUMAH SAKIT DI PROVINSI LAMPUNG
}

\author{
Ajeng Dwi Imelda*, Yeyen Putriana** \\ *Alumnus Jurusan Kebidanan Potekkes Tanjungkarang \\ ** Dosen Jurusan Kebidanan Poltekkes Tanjugkarang
}

\begin{abstract}
Preeklampsia berat dan eklampsia merupakan komplikasi dalam kehamilan dan persalinan yang meningkatkan angka kesakitan dan kematian ibu dan bayi. Peningkatan gejala dan tanda tersebut jika tidak cepat ditangani akan dapat membahayakan keadaan ibu dan bayi. Hasil pre survey di pada tahun 2016 di RSUD H.Abdul Moeloek Provinsi Lampung sebanyak 46 kasus kematian ibu di sebabkan oleh eklamsia. Tujuan dalam penelitian ini adalah untuk mengetahui penanganan awal kejadian preeklampsia berat dan eklampsia. Rancangan Penelitian ini deskriptif dengan pendekatan cross sectional. Pada penelitian ini teknik sampling yang digunakan adalah Accidental Sampling yang populasi seluruh ibu bersalin yang mengalami Preeklmpsia Berat dan Eklamsia pada Tahun 2017. Pengumpulan data menggunakan chek list dengan analisa univariat. Populasi yang di dapatkan saat penelitian berjumlah 25 responden. Berdasarkan hasil penelitian yang dilakukan di Ruangan Kebidanan RSUD. Dr. Hi Abdul Moeloek tahun 2017 diperoleh bahwa diantara yang mengalami preeklampsia berat 17 responden, terdapat $14(82.4 \%)$ responden yang mendapatkan penatalaksanaan sesuai protap, sedangkan $3(17.6 \%)$ responden tidak mendapatkan penatalaksanaan sesuai protap. Dan yang mengalami eklampsia 8 responden, terdapat $6(75.0 \%)$ responden yang mendapatkan penatalaksanaan sesuai protap sedangkan 2 $(25.0 \%)$ responden tidak mendapatkan penatalaksanaan sesuai protap. Saran yang diberikan peneliti agar petugas kesehatan untuk meningkatkan kualitas pelayanan kesehatan dengan memberikan penatalaksanaan preeklampsia berat dan eklampsia sesuai protap, sehingga dapat menurunkan angka kematian disebabkan eklamsia baik di tingkat provinsi maupun secara nasional.
\end{abstract}

Kata Kunci: Eklamsia, Penatalaksanaan, Preeklampsia berat, Eklampsia

\section{LATAR BELAKANG}

Preeklamsia ialah penyakit dengan tanda-tanda hipertensi, odema dan proteinuria yang timbul karena kehamilan pada usia kehamilan diatas 20 minggu . Penyebabnya belum diketahui. Pada kondisi preeklamsia berat dapat menjadi eklamsia dengan dengan penambahan kejang-kejang (Prawirohardjo, 2009). Peningkatan gejala dan tanda tersebut jika tidak cepat di tangani akan dapat membahayakann keadaan ibu dan bayi.

Preeklamsia dan eklamsia merupakan penyebab utama mortalitas dan morbiditas ibu dan bayinya. Indikasi preeklamsia adalah $7-10 \%$ dari kehamilan dan merupakan penyebab kematian ibu nomor dua di Indonesia. Preeklamsia juga dapat menyebabkan gangguan perubahan janin dan kematian janin dalam kandungan (Bekti Subakir, 2008). Untuk mencegah terjadinya masalah eklamsia maka harus di lakukan penangan preeklamsia awal dengan baik

Keberhasilan upaya kesehatan ibu, di antaranya dapat dilihat dari indikator Angka Kematian Ibu (AKI). Indikator ini tidak hanya mampu menilai program kesehatan ibu, terlebih lagi mampu menilai derajat kesehatan masyarakat, karena sensitifitasnya terhadap perbaikan pelayanan kesehatan, baik dari sisi aksesibilitas maupun kualitas. Berdasarkan hasil Survei Penduduk Antar Sensus (SUPAS) 2015, AKI menunjukkan 305 kematian per 100.000 kelahiran hidup. (Kemenkes RI, 2015).

Angka ini masih cukup tinggi jika dibandingkan dengan negara-negara tetangga di Kawasan ASEAN. Pada tahun 2007, ketika AKI di Indonesia mencapai 228 per 100.000 kelahiran hidup, AKI di Singapura hanya 6 per 100.000 kelahiran 
hidup, Brunei 33 per 100.000 kelahiran hidup, Filipina 112 per 100.000 kelahiran hidup, serta Malaysia dan Vietnam samasama mencapai 160 per 100.000 kelahiran hidup (Kemenkes RI, 2014)

Menurut Depkes RI (2010), penyebab langsung kematian maternal di Indonesia terkait kehamilan dan persalinan terutama yaitu perdarahan $28 \%$, eklamsia $24 \%$, infeksi $11 \%$, partus lama $5 \%$, dan abortus 5\%. Sedangkan di Provinsi Lampung tahun 2013, kematian ibu disebabkan oleh perdarahan sebanyak 47 kasus, eklamsia sebanyak 46 kasus, partus lama sebanyak 1 kasus, aborsi sebanyak 1 kasus, dan lain-lain sebanyak 54 kasus. (Profil kesehatan provinsi Lampung, 2014).

\section{METODE}

Jenis penelitian ini adalah deskriptif yaitu suatu metode penelitian yang dilakukan dengan tujuan memberikan gambaran atau mendeskripsikan tentang suatu keadaan secara objektif. dengan pendekatan cross-sectional yang akan meneliti Gambaran Penanganan Awal Kejadian Preeklamsia Berat dan Eklampsia di RSUD Dr. H. Abdul Moeloek Provinsi Lampung.

Populasi adalah keseluruhan objek yang akan diteliti. Populasi yang diambil pada penelitian ini yaitu seluruh ibu yang mengalami preeklamsia Berat dan Eklampsia di RSUD Dr. H. Abdul Moeloek Provinsi Lampung. Sampel dari penelitian ini yaitu sebagaian ibu yang mengalami preeklamsia dan eklampsia di RSUD Dr. H. Abdul Moeloek provinsi Lampung. Untuk mendapatkan sampel yang mewakili karakteristik populasi, maka sampel yang digunakan adalah non random sampling dengan teknik metode Accidental Sampling, pengambilan sampel secara aksidental (accidental) ini dilakukan dengan pengambilan kasus atau responden yang kebetulan ada atau tersedia disuatu tempat sesuai dengan konteks penelitian. Waktu penelitian pada bulan April - Mei 2017. Sedangkan lokasi penelitian ini dilakukan di RSUD Dr. H. Abdul Moeloek Provinsi Lampung.

Teknik analisa data yang akan digunakan dalam penelitian ini adalah analisa data secara univariat, yaitu data yang mendeskripsikan atau menggambarkan data tersebut dalam prosentase yang disajikan dalam bentuk tabel distribusi frekuensi.

\section{HASIL}

\section{Analisis Univariat}

Tabel 1: Distribusi Frekuensi Responden Berdasarkan Penatalaksanaan Awal kepada Ibu Bersalin yang Mengalami Preeklamsia Berat dan Eklampsia

\begin{tabular}{lcc}
\hline \multicolumn{1}{c}{ Katagori } & f & $\%$ \\
\hline Preeklamsia Berat & 17 & 68 \\
\hline Eklampsia & 8 & 32 \\
\hline Jumlah & 25 & 100 \\
\hline
\end{tabular}

Berdasarkan tabel di atas terlihat kejadian preeklampsia berat sebanyak 17 responden (68 \%) lebih banyak dibandingkan eklamsia

Tabel 2: Distribusi Fekuensi Responden Berdasarkan Penatalaksanaan Awal Kepada Ibu Bersalin yang Mengalami Preeklamsia Berat

\begin{tabular}{lcc}
\hline \multicolumn{1}{c}{ Katagori } & f & $\%$ \\
\hline Sesuai protap & 14 & 82,4 \\
\hline Tidak sesuai protap & 3 & 17,6 \\
\hline Jumlah & 17 & 100 \\
\hline
\end{tabular}

Berdasarkan tabel di atas terlihat yang mendapatkan penatalaksanaan sesuai protap sekitar $14(82.4 \%)$ pada ibu yang mengalami preeklampsia berat. 
Tabel 3: Distribusi Fekuensi Responden Berdasarkan Penatalaksanaan Awal Kepada Ibu Bersalin yang Mengalami Eklamsia

\begin{tabular}{lcc}
\hline Katagori & f & $\%$ \\
\hline Sesuai protap & 6 & 75,0 \\
\hline Tidak sesuai protap & 2 & 25,0 \\
\hline Jumlah & 8 & 100 \\
\hline
\end{tabular}

Berdasarkan tabel di atas terlihat yang mendapatkan penatalaksanaan sesuai protap sekitar $(75.0 \%)$ pada ibu yang mengalami eklamsia.

\section{PEMBAHASAN}

\section{Preeklampsia Berat dan Eklampsia}

Berdasarkan hasil penelitian yang dilakukan di Ruangan kebidanan RSUD. Dr. Hi Abdul Moeloek Tahun 2017 diperoleh bahwa di antara 17 responden $(82.4 \%)$ yang merupakan kasus Preeklampsia berat dan 8 responden (75.0\%) merupakan kasus Eklamsia.

Hal ini sesuai teori menyatakan Preeklampsia dan eklamsia merupakan penyebab utama mortalitas dan morbiditas ibu dan bayinya. Indikasi preeklamsia adalah 7-10\% dari kehamilan dan merupakan penyebab kematian ibu nomor dua di Indonesia. Preeklamsia juga dapat menyebabkan gangguan perubahan janin dan kematian janin dalam kandungan. Umumnya terjadi pada trimester ketiga. Persentasenya adalah $5-10 \%$ kehamilan kecenderungannya meningkat pada faktor genetis. Berbeda dengan tekanan darah tinggi menahun, preeklampsia ialah kondisi peningkatan tekanan darah yang terjadi ketika hamil. Preeklampsia lebih sering terjadi pada ibu yang mengalami kehamilan yang pertama kali (7\%). Wanita yang hamil berusia 35 tahun, hamil kembar, menderita diabetes, tekanan darah tinggi dan gangguan ginjal juga mempunyai risiko menderita preeklampsia. (Indiarti, 2009).

Preeklamsia adalah timbulnya hipertensi disertai proteinuria dan odema akibat kehamilan 20 minggu atau segera setelah persalinan. preeklamsia berat dapat menjadi eklamsia dengan dengan penambahan kejang-kejang. eklamsia yang diseratai kejang dan koma yang timbul bukan akibat kelainan neurologi.

Pereklamsia berat dengan tekanan darah sistolik $\geq 160 \mathrm{mmHg}$ dan tekanan darah diastolic $\geq 110 \mathrm{mmHg}$ disertai lebih $5 \mathrm{~g} / 24$ jam (Sarwono, 2008)

Preeklampsia terjadinya karena adanya mekanisme imunolog yang kompleks dan aliran darah ke plasenta berkurang. Akibatnya jumlah zat makanan yang dibutuhkan janin berkurang. Makanya, preeklampsia semakin parah atau berlangsung lama bisa menghambat pertumbuhan janin. Preeklampsia menyebabkan tubuh ibu 'teracuni' dan membahayakan janin. Gejalanya adalah pembengkakan pada beberapa bagian tubuh, terutama muka dan tangan. Lebih gawat lagi apabila disertai peningkatan tekanan darah secara tiba-tiba, serta kadar protein yang tinggi pada urin (Indiarti, 2009).

Menurut penelitian Dhora Dwi Palupi dan Rachmah Indawati pada tahun 2013. Penyebab utama kematian ibu adalah preeklampsia/eklampsia dan perdarahan. Tujuan dari penelitian ini untuk melihat besar risiko preeklampsia/eklampsia dan perdarahan yang berakibat pada kematian ibu di Jawa Timur.

Menurut peneliti, jika ibu bersalin mengalami hipertensi akan meningkatkan risiko mengalami Preeklampsia Berat dan Eklampsia. Maka dari itu, disarankan segera melakukan rujukan pada fasilitas kesehatan yang lebih lengkap apabila ditemui ibu hamil dengan risiko Preeklampsia Berat dan Eklampsia.

\section{Penatalaksanaan Preeklampsia Berat dan Eklampsia}

Berdasarkan hasil penelitian yang dilakukan di Ruangan Kebidanan RSUD. Dr. Hi Abdul Moeloek tahun 2017 diperoleh bahwa diantara yang mengalami preeklampsia berat 17 responden, terdapat $14(82.4 \%)$ responden yang mendapatkan penatalaksanaan sesuai protap, sedangkan $3(17.6 \%)$ responden tidak mendapatkan 
penatalaksanaan sesuai protap. Dan yang mengalami eklampsia 8 responden, terdapat $6 \quad(75.0 \%)$ responden yang mendapatkan penatalaksanaan sesuai protap sedangkan $2(25.0 \%)$ responden tidak mendapatkan penatalaksanaan sesuai protap.

\section{Prosedur Penatalaksanaan Pre- eklampsia Berat}

Perawatan konservatif

1. Indikasi Pada kehamilan $\langle>=180$ $\mathrm{mmHg}$ atau diastole $>=110 \mathrm{mmHg}$

2. Pengobatan

a. Di kamar bersalin (selama 24 jam)

1) Tirah baring

2) Infus RL (Ringer Laktat) yang mengandung 5\% dekstrosa, 60$125 \mathrm{cc} / \mathrm{jam}$,

3) 10 gr $\mathrm{MgS0} 040 \%$ i.m. sebagai dosis awal diulangi dengan dosis 5 gr $\mathrm{MgSO} 450 \%$ i.m. setiap 6 jam, s/d 24 jam pascapersalinan (kalau tidak ada kontra indikasi pemberian MgS04 )

4) Diberikan anti hipertensi: yang digunakan:

- Klonidin suntikan i.v. (1 ampul mengandung $0,15 \mathrm{mg} / \mathrm{cc}$ ), tersedia di kamar bersalin, dilanjutkan tablet

- Nifedipin 3 x $10 \mathrm{mg}$ (pilihan pertama) atau tablet Metildopa $3 \times 250 \mathrm{mg}$ )

- Bila sistole $>=180 \mathrm{mmHg}$ atau diastole $>=110 \mathrm{~mm} \mathrm{Hg}$ digunakan injeksi 1 ampul Klonidin yang mengandung $0,15 \mathrm{mg} / \mathrm{cc}$. Klonidin 1 ampul dilarutkan dalam 10 cc lar.aquadest (untuk suntikan). Disuntikan : mula-mula 5 cc i.v. perlahan-lahan selama 5 menit. 5 menit kemudian tekanan darah diukur, bila belum ada penurunan maka diberikan lagi sisanya 5 cc i.v. dalam 5 menit sampai tekanan darah diastole normal.
5) Dilakukan pemeriksaan lab. tertentu (fungsi hepar dan ginjal) dan produksi urine 24 jam.

6) Konsultasi dengan spesialis Mata, Jantung atau yang lain sesuai indikasi.

b. Pengobatan dan evaluasi selama rawat tinggal di Ruang Bersalin setelah 24 jam masuk ruangan bersalin)

1) Tirah baring

2) Obat-obatan:

- Roboransia: multivitamin

- Aspirin dosis rendah 1 x 87,5 mg per hari

- Antihipertensi (Klonidin 0,15 mg i.v. dilanjutkan Nifedipin $3 \mathrm{x}$ $10 \mathrm{mg}$ atau Metildopa 3 x 250 $\mathrm{mg}$ )

3) Pemeriksaan lab.:

- Hb, PCV dan hapusan darah tepi

- Asam urat darah

- Trombosit

- Fungsi ginjal/hepar

- Urine lengkap

- Produksi urine per 24 jam, penimbangan BB setiap hari

- Diusahakan pemeriksaan AT III

- Pemeriksaan Lab dapat diulangi sesuai dengan keperluan.

4) Diet tinggi protein, rendah karbohidrat

5) Dilakukan penilaian kesejahteraan janin.

6) Perawatan konservatif dianggap gagal bila:

- Adanya tanda-tanda impending eklampsia

- Kenaikan progresif dari tekanan darah

- Adanya Sindrom Hellp

- Adanya kelainan fungsi ginjal

- Penilaian kesejahteraan janin jelek.

Perawatan aktif

1. Indikasi

a. Hasil penilaian kesejahteraan janin jelek

b. Adanya gejala-gejala impending eklamsia 
c. Adanya Sindrom Hellp

d. Kehamilan aterm (> $38 \mathrm{mg}$ )

Apabila perawatan konservatif gagal (lihat 3)

2. Pengobatan medisinal

a. Segera rawat inap

b. Tirah baring miring kesatu sisi

c. Infus RL yang mengandung 5\%

Dekstrosa dengan 60-125 cc/jam

d. Pemberian anti kejang: MgS04 Dosis awal:

1) $\mathrm{MgSO} 420 \% 2$ gr.i.v.

2) $\mathrm{MgSO} 4 \quad 50 \% \quad 10 \quad$ gr $\quad$ i.m. pada bokong kanan/kiri (masingmasing 5 gr)

Dosis ulangan:

1) $\mathrm{MgSO} 450 \% \quad 5$ gr.i.m.diulangi tiap 6 jam setelah dosis awal s/d 6 jam pasca persalinan.

Syarat pemberian:

- Refleks patela (+)

- Respirasi > 16/menit

- Urine sekurang-kurangnya 150 cc/6 jam

- Harus selalu tersedia kalsium glukonas 1 gr 10\%(diberikan i.v. pelan-pelan pada intoksikasi MgS04)

e. Antihipertensi dapat dipertimbangkan diberikan bila:

(Klonidin i.v. dilanjutkan Nifedipin 3

x 10 atau Metildopa 3 x $250 \mathrm{mg}$ )

- Systole > $180 \mathrm{mmHg}$

- Diastole > $120 \mathrm{mmHg}$

Protap Penatalaksanaan Eklampsia pertolongan pertama saat di IGD hindari ransangan, Pasang spatula lidah Bebaskan jalan napas Beri : MgSO4 $20 \% 4 \mathrm{~g}(20 \mathrm{cc})$ I.V pelan-pelan MgSO4 $40 \% 8 \mathrm{~g}(10 \mathrm{cc})$ I.M ( $10 \mathrm{cc}$ BoKa $+10 \mathrm{cc}$ BoKi ) Pasang infus D5\% atau RL Fiksasi badan di tempat tidur 15 - 30 menit. kirim ke upf obgyn eklampsia di upf obgyn Pertolongan lanjut di kamar bersalin atau ruang isolasi: Periksa dalam Pasang kateter menetap Lanjutan MgSO4 $40 \% 10$ cc I.M tiap 6 jam Bila kejang lagi $\Rightarrow$ MgSO4 $20 \% 10 \mathrm{cc}$ I.V Bila kejang lagi setelah 20' Pentothal $5 \mathrm{mg} / \mathrm{kgBB} / \mathrm{I} . \mathrm{V}$ pelan-pelan atau Amibarbital 3-5 mg/kgBB/I.V pelan-pelan Obat-obat penunjang (Antihipertensi,
Antibiotik, Diuretik, Kardiotonik) Periksa lab darah, urin, liver enzym Setelah terjadi stabilisasi 4-8 jam setelah : - kejang terakhir - pemberian anti kejang/anti hipertensi terakhir - mulai sadar terminasi kehamilan tanpa memandang usia kehamilan dengan trauma seminimal mungkin pada ibu belum inpartu Pervaginam Induksi dengan pitosin + Amniotomi Sebaiknya bila Bishop skor $>8$ Perabdominam Bila ada K.I induksi - 12 jam drip tidak masuk fase aktif inpartu kala I 6 jam fs laten tidak fase aktif sebaiknya - fase aktif : pitosin + amniotomi kala II ef / ev .

RSUD Dr. H. Abdul Moeloek Povinsi Lampung tidak melakukan pemberian MgSO4 secara IM karena petugas menerapkan asuhan sayang ibu, pemberian $\mathrm{MgSO} 440 \% 4 \mathrm{~g}(10 \mathrm{cc})$ di berikan secara bolus dan MgSO4 40\% $6 \mathrm{~g}$ drip dengan RL selama 6 jam 30 tetes/menit. Pemberian MgSO4 dapat di berikan jika Refleks patela (+) respirasi > 16/menit, urine sekurangkurangnya $150 \mathrm{cc} / 6$ jam.

Menurut penelitian Indah Budiarti sebagian besar responden telah melakukan penatalaksanaan preeklampsia berat namun belum sesuai dengan standar. Dan dari penelitian Indah Budiarti ditemukan adanya hubungan penatalaksanaan preeklampsia berat pada tingkat pelayanan dasar terhadap kejadian eklampsia di RSUD Dr. H. Abdul Moeloek Bandar Lampung tahun 2012. Menurut Peneliti, Penatalaksanaan awal kejadian preeklampsia berat dan eklampsia di RSUD Dr. H. Abdul Moeloek Povinsi Lampung harus lebih di tingkatkan kembali dan untuk para petugas kesehatan diharapkan memperbarui pengetahuan dan ilmu serta mengikuti pelatihan-pelatihan yang terbaru dalam penatalaksanaan preeklampsia berat dan eklampsia .

\section{KESIMPULAN}

Berdasarkan hasil penelitian dan pembahasan tentang penanganan awal preeklampsia berat dan eklampsia di 
RSUD Dr. H. Abdul Moeloek Propinsi Lampung di RSUD tahun 2017 dapat disimpulkan sebagian besar ibu yang mengalami preeklampsia berat sebanyak 17 responden dan Eklampsia sebanyak 8 responden., Sebagian besar yang mengalami preeklampsia berat, terdapat 14 $(82.4 \%)$ responden yang mendapatkan penatalaksanaan sesuai protap.Sebagian besar yang mengalami eklampsia, terdapat $6(75.0 \%)$ responden yang mendapatkan penatalaksanaan sesuai protap.

Saran bagi tempat penelitian agar dapat meningkatkan mutu dan kualitas pelayanan kesehatan dengan memberikan penatalaksanaan preeklampsia berat dan eklasmpsia sesuai protap. Bagi Bidan dan Tenaga Kesehatan Lainnya untuk petugas kesehatan diharapkan memperbarui pengetahuan dan ilmu serta memberikan pelatihan-pelatihan yang terbaru dalam penatalaksanaan preeklampsia berat dan eklampsia.

\section{DAFTAR PUSTAKA}

Dinas Kesehatan Provinsi Lampung. 2010. Profil Kesehatan Provinsi Lampung

Pudiastuti, Ratna Dewi. 2011. Asuhan Kebidanan pada Hamil Normal \& Patologi. Nuha Medika: Yogyakarta

Sarwono, Prawirohardjo. 2005, Ilmu Kebidanan. PT. Bina Pustaka : Jakarta

Sarwono, Prawirohardjo. 2011, Ilmu Kebidanan. PT. Bina Pustaka : Jakarta 